\title{
A lei natural e a lei escrita: uma leitura à luz do pensamento de Nietzsche
}

\author{
Natural law and written law: a reading from Nietzsche's perspective
}

\section{Rogério Miranda de Almeida}

Doutor em Filosofia pela Universidade de Metz, professor no programa de pós-graduação de Filosofia da Pontifícia Universidade Católica do Paraná (PUCPR), e em Teologia pela Universidade de Estrasburgo - França, professor no programa de pós-graduação de Filosofia da PUCPR. Doutor em Filosofia pela Universidade de Metz (França) e em Teologia pela Universidade de Estrasburgo - França, e-mail: r.mirandaalmeida@gmail.com

\section{Resumo}

Este texto tem dois objetivos principais: apresentar o conceito de "lei natural" e aquilo que seria a sua expressão como "lei escrita" e, depois, reinterpretar este conceito a partir de uma perspectiva nietzschiana. Para alcançar este duplo objetivo urge, pois, em primeiro lugar, traçar, nas suas grandes linhas, as vicissitudes que atravessou a teoria da "lei natural" ao longo da tradição filosófica até a sua culminância naquelas correntes do direito natural, típicas dos tempos modernos. Convém também assinalar que este conceito encerra no seu bojo, como derivações, as noções de necessidade, de finalidade e providência. Eis por que, para interpretá-lo e criticá-lo, são utilizadas algumas intuições e análises de Nietzsche que, ao longo de sua obra, não cessa de se referir, direta ou indiretamente, a estas questões e, também, àquela de acaso. Não se trata, portanto, de 
simplesmente apresentar uma crítica de Nietzsche aos conceitos de "lei natural" e "lei escrita”, mas, principalmente, de examiná-los à luz de seu pensamento.

Palavras-chave: Lei natural. Lei escrita. Logos. Providência. Acaso.

\section{Abstract}

This text has two main aims: 01) to set forth the concept of "natural law" and of what is supposed to be its expression as "written law"; and, 02) to reinterpret this concept from a Nietzschean perspective. In order to reach this double aim, it is necessary, first of all, to summarize the vicissitudes that the theory of "natural law" went through along the philosophical tradition till its culmination in those currents of jusnaturalism, typical of modern times. It is also noteworthy that this concept contains, as its extensions, the notions of necessity, finalism, and providence. This is the reason why, in order to interpret and criticize it, some insights and analyses of Nietzsche are made use of, which, along with his writings, do not cease, directly or indirectly to point out to those issues, as well as to that of chance. It is not, therefore, a question of simply presenting Nietzsche's valuation on "natural law" and "written law", but mainly of examining them under the light of his thought.

Keywords: Natural law. Written law. Logos. Providence. Chance.

Na abertura da peça homônima, Antígona conduz sua irmã, Ismênia, fora do palácio para comunicar-lhe o fatídico edito do novo soberano de Tebas, Creonte, segundo o qual não seria concedida sepultura a um de seus irmãos, Polinício. Com efeito, dos dois irmãos da inditosa Antígona - ambos abatidos no mesmo dia pelas mãos um do outro - o rei ordenara que Etéocles fosse sepultado consoante às normas rituais para que, chegado ao mundo subterrâneo, fosse recebido com as devidas honras pelos demais falecidos. Quanto ao cadáver do mísero Polinício, ele decretara que a nenhum cidadão seria lícito inumá-lo ou pranteá-lo, mas que, ao invés, fosse lançado por terra para servir de pasto às aves do céu. Ora, diante do firme propósito que tomara Antígona de sepultar o irmão, a Ismênia não restava outra alternativa senão a de adverti-la do grave infortúnio em que ambas incorreriam caso não obedecessem à autoridade real e, deste modo, transgredissem a lei 
(SÓFOCLES, 2004, p. 61-65). Não seria, de fato, o próprio Creonte a declarar que não tinha nenhuma consideração por aqueles que demonstravam mais estima por um amigo do que pela pátria? (SÓFOCLES, 2004 , p. 73). Com isto, queria ele significar que somente os "justos" que se dedicam ao serviço e à defesa da pólis - mereceriam receber as honras e o culto que, ao contrário, seriam negados aos seus traidores.

Sepultado, todavia, o irmão, Antígona é conduzida ao cárcere e, mais precisamente, a uma cela subterrânea, onde deverá ser acolhida por aqueles que não são nem vivos nem mortos (SÓFOCLES, 2004, p. 121). Inconsolada e inconformada com a sentença dos homens, ela proferirá uma interrogação que, até hoje, tem dividido os partidários da lei escrita e da lei do coração: "Terei, por acaso, violado a justiça divina? [...] E a quem pedirei ajuda se, pela minha piedade, foi-me imputado o nome de ímpia?" (SÓFOCLES, 2004, p. 125). Este era, pois, o dilema em que fora lançada a heroína da tragédia: ou reconhecer em Creonte o porta-voz da lei do Estado e, consequentemente, submeter-se à justiça que o próprio Estado outorgara ou, pelo contrário, julgar tal ação não como uma virtude de Estado, mas como um delito ou uma atitude criminosa que estava em aberto antagonismo com o amor e o dever familiar de sepultar o irmão. No primeiro caso, estaríamos diante do chamado direito positivo, que compreende o direito escrito e o direito consuetudinário; no segundo caso, porém, prevaleceriam o bom senso e a equidade, que apontam para o convencionalmente denominado direito natural. Este último seria dotado de leis preexistentes às leis positivas e, por conseguinte, estaria fundado numa suposta natureza do homem ou, mais amplamente, numa lei natural que, em última instância, seria responsável pela própria ordem do universo.

Mas em que finalmente consiste a teoria da lei natural? Haveria - inscrita no seio da natureza - uma racionalidade, uma ordem ou um logos do qual a lei positiva, as ações e a linguagem humanas seriam, por assim dizer, as manifestações visíveis, tangíveis, experienciáveis? Melhor: teria este conceito uma fundamentação empírica, ou se trataria simplesmente de uma convenção a mais, de uma ficção a mais? Certo, essas interrogações poderiam nos reconduzir à antiga controvérsia escolástica em torno do nominalismo, do realismo e de suas derivações; o que não 
seria totalmente inútil. Mas este não é o meu escopo. Tenciono tão-somente fazer ressaltar as principais vicissitudes pelas quais passou este conceito ao longo da história do pensamento para, depois, tecer algumas considerações - a partir da perspectiva de Nietzsche - em torno de uma suposta racionalidade e finalidade inscritas na natureza. Comecemos, pois, por apresentar um ensaio de definição da "lei natural".

\section{A lei natural: tentativa de definição}

Num primeiro momento, se a considerarmos a partir de uma perspectiva histórica, a teoria da lei natural poderia ser definida negativamente, no sentido em que as formas típicas sob as quais ela se tem apresentado na Antiguidade, na Idade Média, na Idade Clássica e na fase contemporânea indicam - a despeito dos devaneios de Rousseau e do mito narrado por Hesíodo em Os trabalhos e os dias - que em vão se procuraria um "estado de natureza" no qual as sociedades humanas, os Estados e as comunidades políticas teriam atravessado uma "idade de ouro" antes de sua formação propriamente dita. O próprio conceito de "natureza" não é um conceito unívoco, na medida em que ele pode significar:

a) um princípio de vida, de energia, de espontaneidade e de movimento em todas as coisas existentes, ou ainda, a forma, a substância ou a causa dos seres que contêm em si o princípio de seu próprio movimento (Aristóteles);

b) uma ordem, uma necessidade ou uma lei imanente ao próprio mundo, como o entendiam os estoicos;

c) uma imagem do pensamento ou o último termo da alma que agora se tornou um simples acidente ou um mero reflexo da inteligência (Plotino);

d) o equivalente de hipóstase e/ou ousia (em latim: substantia) nos debates cristológicos do século IV;

e) a causalidade (natura naturante) e a própria totalidade dos seres (natura naturata) na escolástica latina; 
f) a essência, a forma, o impulso espontâneo e, ainda, Deus e a concatenação das coisas criadas (Descartes);

g) a fonte do conhecimento que, originária e estruturalmente, se diferencia daquela da revelação (Spinoza);

h) o conjunto de todos os objetos da experiência e, também, a regularidade dos fenômenos no tempo e no espaço (Kant);

i) a Ideia na forma de ser outro ou, mais precisamente, na forma da exterioridade (Hegel).

No que diz respeito à "lei natural", existem, na perspectiva de Tomás de Aquino, as proposições da filosofia moral e política, a partir das quais se analisam as normas que, justamente, derivam de uma suposta lei inscrita na natureza. Existem também as proposições que constituem as ciências da natureza e os princípios que regem a disciplina da lógica. Existem, enfim, os princípios e as normas que se referem a toda técnica humana apta a manipular os objetos submetidos à nossa vontade. Todavia, para o Aquinata, a lei natural está essencialmente subordinada à lei eterna. Com efeito, das quatro causas que Aristóteles apresenta já no Livro A da Metafísica, e que a Escolástica transformará, sob a forma de adjetivos, em causa material, causa formal, causa eficiente e causa final, foi esta última a que mais impacto exerceu sobre a história da moral ocidental. Assim, toda regra - entendida como norma, preceito e, em última análise, razão - tem como alvo essencial uma comunidade. Como, porém, a maior e mais abrangente de todas as comunidades é o próprio mundo governado por Deus, segue-se que a norma última e suprema de todas as coisas é a lei eterna que dele dimana. No que tange especificamente aos seres humanos, quanto mais racionais forem eles, tanto mais também tenderão para Deus ou, dito de outro modo: os seres humanos têm, na visão do Aquinata, uma aspiração ou uma inclinação natural para o seu verdadeiro e último fim, que se encontra na mente ou na razão divina (AQUINO, 1975, v. 3, II, p. 120-125). Mas, considerando-se que esta já é uma reelaboração, em linguagem cristã, do conceito de "lei natural" que Tomás de Aquino tomara de empréstimo à filosofia grega, a questão que agora se impõe é a de saber em que finalmente consistem o surgimento e desenvolvimento desta teoria. 


\section{Emergência e desenvolvimento do conceito}

Com efeito, se recuarmos ainda mais, veremos que as primeiras elaborações da lei, considerada como razão inerente à própria natureza, já se encontram no período arcaico da cultura helênica que se estende, mais ou menos, de 800 , ou 750, a 500 a. C. De acordo com a interpretação de Werner Jaeger - interpretação, de resto, contestável - foi a partir das noções de justiça e de ordem, verificadas no agir humano da pólis, que se descobriu uma homologia ou correspondência entre esta mesma ordem e aquela que rege a natureza e, enfim, o universo ou o cosmos (JAEGER, 1973, p. 154). E, de fato, um fragmento atribuído por Simplício a Anaximandro suscita, entre outras, a interpretação segundo a qual este pré-socrático teria transferido a noção de justiça (dike) do espaço social humano para o reino da natureza, embora o suposto texto de Anaximandro não mencione a palavra "natureza" (REALE, 2006, p. 197). Em Heráclito, essa lei que regeria todas as coisas adquire também o sentido de pensamento (gnome) e razão (logos), pois, além de significar "palavra", "narrativa" e "descrição", o logos se apresenta igualmente como a ordem, ou a lei, a partir da qual "todas as coisas nascem e morrem” (REALE, 2006, p. 341). Parece, no entanto, ter sido Pitágoras o primeiro a ter designado o mundo pelo nome de "cosmos" para com ele exprimir as noções de ordem, conveniência e beleza. A conclusão de Pitágoras teria sido, portanto, esta: se os seres humanos querem realmente identificar-se com este cosmos, com o qual acreditam possuir uma relação essencial de afinidade, eles devem, em primeiro lugar, estudar o seu comportamento e tentar descobrir o que finalmente ele é. Isso os levaria a se aproximarem cada vez mais dele e, consequentemente, a plasmarem suas vidas em conformidade com os princípios e as leis que ele manifesta. Na medida, pois, em que o universo se revela como um cosmos, ou seja, um todo harmoniosamente ordenado, os seres humanos também, tomados na sua individualidade, se apresentam como cosmos em miniatura ou, mais exatamente, como microcosmos. Nessa perspectiva, nós seríamos organismos que reproduzem ou resumem os princípios e as leis que regem e estruturam o macrocosmo. De sorte que, ao escrutarmos os seus princípios estruturantes, nós estaríamos, 
por isto mesmo, estudando e desenvolvendo os elementos de forma e de ordem que também nos compõem. De igual modo, o filósofo, ao sondar esse cosmos, tornar-se-ia ele próprio kósmios, vale dizer, convenientemente ordenado e estruturado na sua alma e nas suas ações (GUTHRIE, 1975, p. 37-38).

No período clássico da Grécia e, mais precisamente, na segunda metade do século $\mathrm{V}$, assistimos ao surgimento de um intenso confronto com Sócrates e os sofistas - a respeito da lei natural e da lei enquanto convenção ou, como diríamos hoje, enquanto lei positiva. De fato, no Górgias, Platão introduz a figura do sofista Cálicles para contra-atacar, entre outras, a doutrina segundo a qual haveria uma distinção natural entre o certo e o errado, entre o bem e o mal. De resto, a diferenciação entre physis (natureza) e nomos (lei, norma) é uma das principais inovações que caracteriza o movimento sofístico na medida em que, em linha geral, este movimento tendia a valorizar o papel do nomos enquanto norma reveladora da capacidade humana de construir sua própria cultura, sua própria história, seu próprio destino. Ademais, esse privilégio assinalado ao nomos seria um corolário ou, mais exatamente, uma implicação da crítica sofística contra a moral e a religião tradicionais que se tinham arrogado o direito de divinizar a physis envolvendo-a, assim, com um halo de transcendência, de sublimidade, de intocabilidade. Com o passar do tempo, porém, a mesma physis teria sido submetida a uma interpretação cada vez mais imanente e laicizada até tornar-se uma forma de impulsão elementar, fundamental, contraposta e resistente ao caráter artificial das leis. É neste sentido que a consideram, a partir de suas próprias perspectivas, os sofistas: Hípias no Protágoras, Cálicles no Górgias, Trasímaco e Glauco respectivamente nos Livros I e II da República. No Górgias, 482e, Cálicles, ao contrapor-se à doutrina socrática segundo a qual é mais vil cometer uma injustiça que suportá-la, apela para a distinção, tipicamente sofística, entre physis e nomos (PLATÃO, 1975, p. 383). Aqui, todavia, fazendo eco a uma interpretação da physis que se encontra em Protágoras (337d) e na República (Livro I e Livro II, 358e-359b), Cálicles a considera como uma forma de instinto ou de impulsão primordial que se opõe à ordem ou ao conjunto das normas instituídas artificialmente pela pólis. Depois de haver insistido sobre 
essa distinção, ele chegará à conclusão de que aquele que se impõe pela força age segundo a lei da justiça ou, mais precisamente, em conformidade com a lei da natureza (PLATÃO, 1975, p. 385-387). Esta parece, portanto, ser a primeira menção, na filosofia grega, daquilo que posteriormente será conhecido sob a expressão: "lei natural".

Na Retórica, Aristóteles fará uma distinção entre a lei universal (nómos koinós) e a lei particular (nomos idios). Esta última se refere à lei, ou ao conjunto de leis, que toda comunidade estabelece e aplica aos seus próprios membros; elas podem ser em parte escritas e, em parte, orais. Já a lei universal é a lei da natureza (physis), porquanto - enfatiza o filósofo - existe realmente uma justiça e uma injustiça naturais que são vinculantes para todos os homens, mesmo para aqueles que não vivem em associação ou não selaram nenhum pacto entre si (ARISTÓTELES, 1941, p. 1370). É interessante notar que, nessa mesma passagem, Aristóteles menciona explicitamente o nome de Antígona ao lembrar que, para a heroína, o sepultamento de Polinício era considerado um ato justo - justo por natureza - a despeito da proibição do rei ${ }^{1}$. Tendo-se, pois, iniciado no período arcaico e se explicitado, a partir de perspectivas diferentes, no pensamento clássico, o conceito de "lei natural" será retomado e reelaborado pela filosofia helenística e, nomeadamente, pelo estoicismo.

\section{A lei natural e o estoicismo}

Efetivamente, a teoria da lei natural deveria passar, depois de Platão e Aristóteles, por uma reformulação e reelaboração no seio do pensamento estoico, que teve a sua fundação por volta de 312/311 a. C. Sabe-se, contudo, que o estoicismo é um movimento extenso e compósito. Todavia, a partir e por meio do emaranhado de fragmentos, evoluções e reinterpretações que o caracteriza no seu conjunto, convencionou-se dividi-lo em três períodos principais:

1 Aristóteles aborda de novo a questão de uma justiça natural e de uma justiça legal, ou convencional, na Ética a Nicômaco (ARISTÓTELES, 1941, p. 1014). 
1) O período antigo (IV-III séc. a. C.), cujo chefe de fila é Zenão de Cítio, a quem sucedeu Cleanto, responsável pelo desenvolvimento de sua doutrina, e Crisipo, que levou a termo a sua sistematização e maturação filosófica.

2) O período médio (II-I séc. a. C.), cujas figuras mais expressivas são Panécio de Rodes e Possidônio de Apameia, que atenuaram os aspectos dogmáticos de sua ética e assumiram posições ecléticas sobre diferentes questões.

3) O período do neo-estoicismo (I-II séc. d. C.), representado por Sêneca, Epicteto e Marco Aurélio, que reduziram aos seus elementos essenciais os temas da lógica e da física, acentuando, no entanto, uma ética de fundo religioso.

Ora, conquanto o estoicismo esteja dividido, do ponto de vista formal, numa lógica, numa física e numa ética, o conceito fundamental que está na base dessas três esferas é o logos, que possui uma dupla acepção. Ele é fogo ou pneuma, isto é, princípio natural vivificante do mundo, porquanto a vida é essencialmente ligada ao calor. Mas ele é também a forma das coisas, na medida em que esta forma se apresenta como o princípio que as torna cognoscíveis, porque elas são racionais. Daí as várias implicações que essa concepção fundamental pôde suscitar:

1) Porque o mundo é constituído e regido pelo fogo-logos, ele passará ciclicamente por infinitas conflagrações e destruições, podendo, no entanto, regenerar-se sempre idêntico a si mesmo.

2) O cosmos é comparável a um grande organismo vivo, cujas partes são todas solidárias entre si.

3) Porque o logos, como razão, penetra todas as coisas, ele domina igualmente todos os acontecimentos, de sorte que, de um lado, tudo é racional e, de outro, tudo é rígida e inelutavelmente determinado.

4) O logos é também representado como um princípio divino que a tudo determina e a tudo provê.

5) Do ponto de vista ético, sendo o homem a manifestação do logos, ou da razão, ele deverá necessariamente procurar aquilo que a fomenta, isto é, a ciência, e, inversamente, deverá fugir a tudo 
aquilo que lhe traria dano, como a ignorância e a ociosidade. Por conseguinte, o sábio será sábio na medida mesma em que agir em conformidade com o logos, podendo, pois, ser sempre infalível e irrepreensível em suas ações.

6) Finalmente, deve-se à ética estoica o fato de ter revalorado a lei positiva enquanto uma expressão ou transcrição da lei natural, ou do logos-princípio.

Esta ênfase dada à lei positiva, ou escrita, como uma explicitação da lei natural terá um impacto considerável sobre o direito romano. De resto, foi por meio dos juristas da época imperial de Roma que realmente entrou em vigor a noção de direito natural para, justamente, significar uma "lei justa". Essa noção de "lei justa" influenciará a concepção de base da justiça tanto nos escritos dos Padres da Igreja, quanto na elaboração do Código Justiniano (528-529 e 534). Considerada como uma espécie de instinto impresso por Deus na mente humana, a lei natural chegava a coincidir com a própria moral, porquanto ela se apresentava como um critério ideal por meio do qual se podiam avaliar os usos, os costumes e as normas jurídicas então existentes. Não esqueçamos, ademais, que foi no mundo latino que, pela primeira vez, surgiu a categoria de pessoa jurídica ou de indivíduo portador de direitos e deveres. Essa categoria era ausente do universo político e do pensamento clássico grego, onde o bem e a prosperidade do indivíduo estavam em função do bem e da prosperidade da pólis. É, com efeito, sintomático o fato de Aristóteles declarar, já no início da Ética a Nicômaco, que mesmo se supondo uma identidade entre o bem individual e o bem da pólis, este último se revela como uma tarefa manifestamente mais digna de ser apreendida e salvaguardada. "Porque o bem é seguramente amável, mesmo quando se o aplica a um indivíduo isolado; mas ele é mais belo e mais divino quando aplicado a uma nação ou a cidades" (ARISTÓTELES, 1941, p. 936). Não foi, portanto, a partir de Rousseau, nem de Voltaire, nem de Montesquieu, nem dos Enciclopedistas, nem da Revolução Francesa, tampouco da independência dos Estados Unidos da América que eclodiu a concepção de "direitos humanos". Essa concepção remonta, na verdade, à cultura e à mentalidade romanas que, em 
contraste com o pensamento grego - onde predominavam as noções de destino, de providência e predeterminação - ressaltavam as ideias de liberdade, de individualidade e autonomia. Daí podermos melhor entender a tensão fundamental que atravessa a produção filosófico-teológica de Agostinho, cujo pensamento se move entre dois planos simbólicos marcadamente diferentes um do outro: de um lado, a liberdade do indivíduo e, de outro, a questão da lei natural, ou divina, que se manifesta pelas razões seminais.

\section{Agostinho de Hipona: a liberdade, as razões seminais e a lei divina}

O problema contra o qual Agostinho teria de lutar até o fim de sua obra consiste, de fato, na questão da finitude da existência e, mais precisamente, nas relações entre o bem e o mal, a liberdade e a necessidade, ou a providência. Neste sentido, constata-se no seu desenvolvimento intelectual uma tríplice influência: além da impressão que lhe causaram a filosofia de Plotino e a descoberta das Escrituras durante o chamado período da conversão, ele foi também marcado pelo pensamento grego antes da era cristã e pela cultura latina. A influência grega, que lhe fora particularmente transmitida por Cícero, diz mais especificamente respeito à questão da providência, da necessidade e da predeterminação dos seres tal como a entendiam os estoicos.

Relembremos, aliás, que essa questão encerra mais de um ponto em comum com o problema da inelutabilidade do destino que, na sua expressão literária, remonta até os trágicos do século $\mathrm{V}$ a. $\mathrm{C}$. e, mais ainda, até os poemas de Homero e Hesíodo. No que tange à filosofia estoica propriamente dita, a questão está intrinsecamente ligada àquela outra das razões seminais - em grego, spermatikoi logoi, e em latim, rationes seminales - que significam as partículas da razão divina, ou as razões de todos os viventes que se acham contidas na Razão, ou no Logos, imanente ao próprio mundo. De resto, todo o universo se apresentava para os estoicos como um organismo vivo, animado. Consequentemente, as razões seminais se estendem à totalidade do cosmos, de sorte que o adjetivo "seminal" exprime tanto a ideia de inclusão da ordem 
racional particular dentro da ordem cósmica - como na semente se acha potencialmente contida toda a planta - quanto a ideia de transformação necessária e racional, implícita no desenvolvimento da semente (RADICE, 2006, p. 635-637). Todavia, não é apenas na sua constituição essencial que as coisas, ao se formarem, já se acham de antemão determinadas a serem aquilo que serão; são também todos os seus acidentes, todas as suas metamorfoses e afecções que se encontram inscritas no seu desenvolvimento e nas gerações que virão depois delas (RADICE, 2006, p. 889). Essa dependência dos seres individuais com relação à ordem ou à razão ínsita no seio do universo será retomada e acentuada por Plotino, que não somente reinterpreta, mas também recomenda a doutrina dos estoicos, pois, diz o filósofo, os estoicos estabeleceram um princípio único que liga e enoda entre si todas as coisas, de modo que todos os seres se realizam consoante às razões seminais. Melhor: essa doutrina "sustenta que toda a nossa conduta e todo o nosso movimento derivam da Alma do todo" (RADICE, 2006, p. 851).

Ora, conquanto a visão agostiniana convirja tanto para a concepção dos estoicos quanto para aquela de Plotino - no sentido em que as razões seminais já se acham de antemão determinadas a serem aquilo que serão - ela difere de ambas no que concerne ao papel da criação ou, mais exatamente, da ação criadora da providência cristã. Baseando-se nas Escrituras e, principalmente, no livro do Gênesis, Agostinho afirma que, de todas as coisas que nascem e crescem neste mundo, acham-se latentes, ou potencialmente ativos em seus elementos materiais, certos germes ocultos (occulta semina) que, justamente, foram criados invisibiliter, potentialiter, causaliter. De sorte que uma coisa são as sementes já visíveis aos nossos olhos a partir dos frutos e dos animais, outra coisa, porém, "são aquelas sementes ocultas com as quais, sob o comando do Criador, a água produziu os primeiros peixes e as primeiras aves, a terra produziu seus primeiros rebentos e seus primeiros animais, segundo a sua espécie" (AGOSTINHO, 1998, p. 112)². O mundo se apresenta as-

2 A doutrina agostiniana das razões seminais se acha mais amplamente desenvolvida na obra, De Genesi ad litteram, que Agostinho terminou em 414, quando ainda redigia o De Trinitate, completado em 426. Para uma análise mais detalhada desta doutrina, veja ARNOULD, J. Les raisons séminales chez Saint Augustin. Augustinianum, Roma, v. 38, n. 2, p. 439-453, 1998. 
sim "grávido" (gravidus) das causas dos seres que estão se tornando, que estão vindo-a-ser, pois assim como as mães estão grávidas de seus fetos, assim também o próprio mundo está grávido das causas das coisas que nascem, crescem e se desenvolvem (AGOSTINHO, 1998, p. 116).

Certo, a doutrina agostiniana de uma providência que a tudo preside e tudo determina é inerente àquela outra de ordem, de razão ou, numa palavra, de governo do mundo. Todavia, por se tratar de uma doutrina caracteristicamente cristã e, portanto, diferente da visão estoica e da teoria plotiniana das hipóstases, ela remete a uma providência que se desenrola, não a partir de um logos do qual o mundo seria a eterna manifestação, nem à maneira de uma sempre existente processão, embora degradada e deformada - porque em contato com as realidades sensíveis -, mas como um ato livre e voluntário do Criador. De resto, os conceitos de liberdade e vontade são os que mais interpretações suscitaram na ética e na antropologia agostinianas, e isto porque o teólogo africano, ao enfatizar o papel da vontade como princípio de toda ação, vincula-a, ao mesmo tempo, ao auxílio da graça e ao governo da providência. Com relação a esta - e como eu já afirmei mais acima - o autor da Cidade de Deus é tributário, além das Escrituras, de uma longa tradição que, remontando às mais longínquas elaborações do pensamento grego, exerceria - sobretudo a partir do estoicismo que ele recebera de Cícero - um forte impacto sobre a sua própria concepção.

Efetivamente, como também já vimos, a partir do fim do século IV a.C. a problemática da lei natural será retomada e reinterpretada pela filosofia estoica, cujo conceito fundamental é o logos na sua dupla acepção. Ele é fogo ou pneuma e, também, a forma dos seres que se apresenta como o princípio que os torna cognoscíveis, porque racionais. Mas o logos se revela também como um princípio divino que a tudo determina e a tudo provê. De resto, porque o logos - enquanto razão - permeia e anima todas as coisas, ele domina a fotiori todos os acontecimentos que se desenrolam no mundo fenomênico. Sendo este logos um princípio racional, segue-se que toda a realidade é rígida e inelutavelmente determinada pelas suas leis eternas e imutáveis. Ora, a lei que a tudo provê e à qual tudo o mais deve submeter-se é vista por Agostinho como uma lei divina, porque oriunda diretamente de Deus, 
seu único autor. Consequentemente, o seu conteúdo, que se manifesta pela lei escrita, ou positiva, deve necessariamente exprimir-se como uma prescrição da razão divina, ou da vontade de Deus. No Livre arbítrio, Agostinho, inspirado no De legibus e em outros escritos de Cícero, designará a lei divina por esta outra expressão: summa ratio, isto é, razão suprema (AGOSTINHO, 2006, p. 913). De resto, esta mesma lei natural, que está na base do direito romano e que Agostinho retoma e reelabora, dando-lhe uma roupagem cristã, será igualmente reinterpretada pelas diferentes doutrinas éticas e políticas da Escolástica, dentre as quais sobressai - como eu mostrei mais acima - a interpretação de Tomás de Aquino. Ela desembocará enfim - já no limiar da modernidade naquela corrente do pensamento jurídico que se designará pelo nome de "jusnaturalismo".

Mais precisamente, foi a partir de um filão inaugurado pelo jurista holandês Hugo Grotius e prolongado - a partir de diferentes perspectivas - por John Locke, Samuel von Pufendorf, Jean-Jacques Rousseau, Immanuel Kant e Johann Gottlieb Fichte, que se operou uma reviravolta no modo tradicional de considerar e interpretar a teoria da lei natural. Com efeito, e em contraste com a visão anterior, o problema principal que estes pensadores deviam agora afrontar - na nova situação socioeconômico-política da Europa - era justamente o de legitimar as instituições e os sistemas legais das diferentes sociedades a partir de fundamentos universais e racionais, e não mais tomando por base uma autoridade que se supunha emanar da ordem política (o Império Romano, por exemplo), ou religiosa (a Igreja na Idade Média). Todavia, mesmo se tendo transferido a ênfase de uma esfera transcendente - como aquela que prevalecera entre os teólogos cristãos na Idade Média - para um plano imanente ao próprio mundo, resta que as ideias de finalidade e providência continuavam a predominar na teoria da lei natural, tal como esta era considerada pela filosofia moderna.

A esta altura, porém, e para retornar ao segundo tema que eu me propus desenvolver, urge examinar - a partir das intuições e das críticas que tecera o autor de Assim falou Zaratustra - a questão de uma suposta providência ou de uma pretensa racionalidade inscrita no seio da natureza. 


\section{Nietzsche: a providência e o"sublime acaso"}

Certo, debalde se tentaria encontrar, na obra de Nietzsche, um estudo sistemático e ordenadamente seguido em torno da providência ou de uma suposta lei natural guiando teleologicamente o curso do universo. E não poderia ser de outro modo, porquanto o seu pensamento e a sua escrita se desenrolam, essencial e radicalmente, de maneira fragmentária, paradoxal, dispersa. Todavia, essas questões - juntamente com aquelas de finalidade, de fatalidade (amor fati), de repetição, de destruição, de criação, de acaso e vontade de potência - foram as que mais obsidiaram o discípulo de Dioniso. Melhor: a questão das forças e das relações de forças se faz presente em todas as fases e em todos os textos do solitário de Sils-Maria.

É bem verdade que no seu primeiro período - que se estende, grosso modo, de 1869 a 1876 e que é caracterizado pelos "escritos trágicos" e por uma crítica à civilização moderna - ainda não se encontra, nos livros publicados por Nietzsche, a expressão vontade de potência ${ }^{3}$. No entanto, o que está em jogo na formação e no desenvolvimento do Estado e da cultura helênica é, na perspectiva de Nietzsche, um fundo de crueldade, de emulação, de superação e sublimação das pulsões de destruição. Neste sentido, a religião em particular, e a arte em geral, se apresentam como meios de dobrar o sofrimento e a dor, de sorte que a existência e o mundo são transformados, transfigurados e, por conseguinte, justificados como fenômenos estéticos. À diferença, portanto, da visão schopenhaueriana - para quem a vontade deve, em última instância, resignar-se e negar-se a si mesma - o que, para Nietzsche, movia a vontade dos gregos era um fundo e um instinto de afirmação, de justificação, de superação ou, numa palavra, de potência.

No seu segundo período produtivo - que eu situo em torno de 1877-1880 e cuja obra central é Humano, demasiado humano - nota-se um deslocamento de acento da estética para a moral e, mais exatamente,

3 Embora a expressão "vontade de potência" só apareça pela primeira vez, nos livros publicados por Nietzsche, em Assim falou Zaratustra (1883-1885), já se constata a sua presença num fragmento póstumo de fim 1876-verão 1877 (NIETZSCHE, 1988, v. 8, p. 425). 
para uma moral de tipo hedonístico, utilitário. Consequentemente, o que agora predomina nas análises que desenvolve o filósofo acerca do homem são as noções de orgulho, de prazer e desprazer, de amor-próprio, de sentimento de potência e instinto de conservação. Em outros termos, o que agora se faz ressaltar na moral nietzschiana são os motivos ou os móbeis responsáveis pelo comportamento e pelas relações humanas. Não obstante isso, ou por isso mesmo, Humano, demasiado humano - e os fragmentos póstumos que se vinculam a esta obra - reservam mais surpresas e paradoxos que uma primeira leitura poderia levar a imaginar.

No terceiro e último período que, na minha interpretação, já começa com Aurora (1881) e se estende até 1888 - último ano da vida produtiva do filósofo - assiste-se a um retorno, entre outros, do tema da estética, juntamente com uma explicitação, uma ampliação e, ao mesmo tempo, um aprofundamento da questão da vontade de potência que está na base das produções culturais e, portanto, das valorações que as caracterizam fundamentalmente. A vontade de potência em Nietzsche é ambígua na medida em que ela pode ser uma vontade de afirmação, de criação, de elevação, de justificação, mas também de negação, de depreciação, de condenação, de destruição. De morte.

Verdade é que, nesse terceiro e último período, Nietzsche se torna mestre da arte de analisar, dissecar, diagnosticar e mostrar em plena luz as forças e as relações de forças que, incessantemente, constroem e destroem, criam e recriam, aniquilam e tornam a edificar. É, pois, notadamente durante essa fase que se poderão melhor entender as críticas e os ataques que ele dirige contra as noções de necessidade, de providência, de ordem, de finalidade e de lei na natureza como sendo outros tantos expedientes pelos quais a moral se metamorfoseou e se disfarçou para melhor dominar. Mas, mesmo antes que o filósofo subtilizasse ao extremo as análises das forças niilistas da decadência, elas já apontavam, no primeiro e no segundo período, para o real pano de fundo que as havia forjado, criado, animado. Assim, no parágrafo 16 de Humano, demasiado humano, ele declara, sem rodeios, que, desde milênios, o homem tem considerado a existência e o mundo com pretensões morais, estéticas, religiosas e, também, com uma cega inclinação 
entremeada de paixão e de medo (NIETZSCHE, 1988, v. 2, p. 36). E se recuarmos ainda mais, vê-lo-emos afirmar - num texto que faz parte de uma série de reflexões sobre a cultura trágica (setembro 1870, janeiro 1871) - que a finalidade na natureza é uma suposição absurda; que não temos o direito de transpor a ação, segundo as nossas representações, para o domínio da natureza, pois o necessário é o único possível. Precisa-se, pois - conclui o filósofo -, de uma inteligência ordenadora das coisas somente lá onde se encontra o erro, vale dizer, na esfera da consciência (NIETZSCHE, 1988, v. 7, p. 115) .

Dez anos depois, num fragmento póstumo de primavera - outono 1881 - onde também se acham inúmeras tentativas de definição e elaboração do conceito basilar da vontade de potência - Nietzsche será ainda mais incisivo e mais veemente ao investir contra uma suposta racionalidade e finalidade inscritas no seio da natureza. Para o filósofo, essa finalidade, que se pretende orientando e governando o egoísmo, o instinto sexual e a efusão luminosa do sol, não passa de efabulações e ficções de uma mente ociosa: "Trata-se, talvez, da última forma da representação de Deus" (NIETZSCHE, 1988, v. 9, p. 447)5.

E, de fato, no parágrafo 109 da Gaia ciência, que o discípulo de Dioniso começou a redigir nessa mesma época (primavera de 1881), encontra-se uma série de admoestações que suscitou e continua a suscitar diferentes e até mesmo contraditórias interpretações. Assim, já quase no fim do texto, ele adverte:

Guardemo-nos de dizer que há leis na natureza. Há somente necessidades: lá, ninguém manda, ninguém obedece, ninguém transgride. E já que sabeis que não há fins, sabeis também que não há acaso: pois é somente ao lado de um mundo de fins que a palavra "acaso" tem sentido (NIETZSCHE, 1988, v. 3, p. 468).

Curiosamente, Nietzsche termina esta série de "guardemo-nos" perguntando-se de maneira enfática:

4 Para uma análise mais aprofundada do problema da finalidade na natureza, veja ALMEIDA, R. M. de. Nietzsche e o paradoxo. São Paulo: Loyola, 2005. Capítulo l, seção 2.

Aqui e nas demais citações que eu farei de Nietzsche, todas as palavras em itálico provêm do próprio Nietzsche. 
Quando todas essas sombras de Deus cessarão de nos obscurecer? Quando teremos a natureza totalmente desdivinizada? Quando nos será permitido, a nós humanos, começarmos a naturalizar-nos com a pura natureza, descoberta como nova, libertada como nova? (NIETZSCHE, 1988, v. 3, p. 469).

Note-se que o filósofo havia encetado essas admoestações apontando para a problemática do mecanicismo e, logo em seguida, para a concepção segundo a qual os astros em redor de nós obedecem a movimentos cíclicos uniformes e perfeitos. Mas, objeta Nietzsche, um simples olhar lançado à Via Láctea seria suficiente para nos sugerir a existência de movimentos muito mais grosseiros e contraditórios. De sorte que o que caracteriza o mundo no seu conjunto não é a ordem ou a boa disposição, mas antes o caos; e isto não em virtude da ausência de necessidade, mas, justamente, de proporção, de concatenação, de forma, de beleza, de sabedoria e, poderíamos ajuntar, de lei. Para Nietzsche, portanto - e a julgar a partir da nossa razão -, os "lances de dados infelizes" constituem de longe a regra, e não as exceções. Todavia, até mesmo a expressão "lance infeliz" - conclui o filósofo - já carrega no seu bojo uma humanização ou, melhor, uma moralização, uma condenação, uma valoração ou uma censura à facticidade dos acontecimentos fortuitos (NIETZSCHE, 1988, v. 3, p. 469).

$\mathrm{Na}$ passagem anteriormente citada, Nietzsche afirma que a palavra "acaso" não tem sentido senão ao lado de um mundo dotado de fins. No entanto, ele não cessa de se referir ao acaso e, quando o faz, frequentemente o associa às metáforas do jogo - com o lance de dados - e da dança. Em Zaratustra, por exemplo, no capítulo intitulado Antes do nascer do sol, o profeta do eterno retorno exclama:

Um pouco de sabedoria já é possível; mas esta abençoada segurança, eu a encontrei em todas as coisas: que elas ainda preferem sobre os pés do acaso - dançar.

Ó céu sobre mim, céu puro! Céu alto! Esta é agora para mim a tua pureza, que não há nenhuma eterna aranha e teias de aranha da razão.

Que tu és para mim uma pista de dança para acasos divinos, que tu és para mim uma mesa de deuses para divinos dados e jogadores de dados! (NIETZSCHE, 1988, v. 4, p. 209-210). 
Convém, no entanto, relevar que o céu se apresenta não somente como uma pista de dança para os divinos acasos, nem somente como um tabuleiro de jogo onde caem e recaem os dados que, em infinitas combinações, lançam os deuses. Ele se transmuda também no próprio acaso, melhor, ele é o acaso, pois: "Sobre todas as coisas está o céu Acaso, o céu Inocência, o céu Acidente, o céu Desenvoltura" (NIETZSCHE, 1988, v. 4, p. 209-210).

Inocência, dança, jogo, desenvoltura e vir-a-ser, eis as qualidades sem as quais não se pode pensar o acaso, que Nietzsche denomina também "Zeus" ou a "grande criança" heraclitiana que, na praia, se compraz em ajuntar pedrinhas e edificar castelos de areia para, logo em seguida, derrubá-los. Diante desse artista, o mundo se desdobra como um imenso tabuleiro de dados do qual o homem faz parte como um de seus mais felizes, mais inesperados e excitantes lances que o deus jamais jogara. Esse homem, diz Nietzsche:

desperta por si um interesse, uma tensão, uma esperança, quase uma certeza, como se por ele se anunciasse algo, se preparasse algo; como se o homem não fosse um fim, mas somente um caminho, um episódio, uma ponte, uma grande promessa [...] (NIETZSCHE, 1988, v. 5, p. 323-324).

Uma grande promessa de criação e recriação, que também supõe a força do destruir e do aniquilar, do plasmar e do remodelar, do dizer e do contradizer. É o que lemos, por exemplo, num fragmento póstumo de verão-outono 1884:

O mais sábio dos homens seria o mais rico em contradições, aquele que tem, por assim dizer, órgãos do tato para todo tipo de homem: e, de quando em quando, seus grandes momentos de grandiosa harmonia - o sublime acaso também em nós! - uma espécie de movimento planetário (NIETZSCHE, 1988, v. 11, p. 182).

Esse fragmento, de sabor pitagórico, encerra mais de uma relação com o parágrafo 277 da Gaia ciência, que tem sintomaticamente por título: Providência pessoal. Nesse texto, Nietzsche menciona explicitamente os deuses de Epicuro, que ele contrasta - alusiva e ironicamente - com 
o Deus cristão da providência. Já no início, o filósofo afirma que existe um ponto culminante na nossa vida que, quando o atingimos, e, apesar de toda a nossa liberdade e a nossa recusa em atribuirmos uma bondade e uma razão providencial ao "belo caos da existência", corremos o risco de, mais uma vez, cairmos prisioneiros da maior servidão espiritual e, assim, passarmos pela mais difícil das provações. Essa provação consiste, curiosamente, em termos de admitir que todas as coisas que a nós sobrevêm - tanto as boas quanto as más - concorrem incessantemente para a nossa vantagem. O mais importante, porém, a sublinhar é que, já no fim, ele se serve novamente da metáfora da música para nos lembrar da conveniência de não superestimarmos o nosso tato quando, às vezes, nos surpreendemos com os maravilhosos acordes que somos capazes de extrair do instrumento que tocamos. Na verdade, conclui o filósofo:

Aqui e acolá alguém toca conosco - o querido acaso: oportunamente ele nos guia pela mão, e a mais sábia providência não saberia inventar uma música mais bela do que aquela que, então, consegue executar a nossa mão insensata (NIETZSCHE, 1988, v. 3, p. 522).

Ora, se agora cotejarmos esses dois textos com o aforismo 322 da Gaia ciência, intitulado Parábola, veremos que eles o "contradizem" pura e simplesmente. Com efeito, se naqueles textos predominavam as ideias de harmonia, de música e movimento planetário, no aforismo 322 é o inverso que se produz, porquanto nele se faz ressaltar a existência de um imenso caos e de um enorme labirinto se desenrolando não somente no universo, mas também no interior de nós mesmos. Assim:

Os pensadores, segundo os quais todos os astros se movem em órbitas cíclicas, não são os mais profundos. Quem olha para dentro de si como para o interior de um vasto espaço e carrega dentro de si galáxias, sabe também o quanto irregulares são todas as galáxias; elas conduzem até ao fundo do caos e do labirinto da existência (NIETZSCHE, 1988, v. 3, p. 552).

Como se pode constatar, aqui não se faz menção nem de uma grandiosa harmonia, nem de uma bela música, tampouco do "querido acaso" nos guiando pela mão. Trata-se, antes, de uma grande desordem 
e de uma imensa dissonância se manifestando pelo movimento irregular dos astros. Todavia, o leitor deve também recordar-se que já no parágrafo 109 da mesma obra - que acima eu evoquei - Nietzsche se mostrara suficientemente explícito ao afirmar: "E já que sabeis que não há fins, sabeis também que não há acaso". Donde a inevitável conclusão: ora o filósofo afirma e reafirma a existência de uma harmonia cósmica, juntamente com o "sublime acaso"; ora ele nega tanto essa harmonia quanto o acaso. Estaríamos, pois, diante de um paradoxo? Sim! E não somente de um paradoxo, mas de inúmeros paradoxos que, dados os limites formais de um artigo, não podem ser aqui destacados e, menos ainda, examinados.

Ademais, o meu propósito não é o de "resolver" os paradoxos da obra nietzschiana, se é que um paradoxo pode ser resolvido ou explicado. De resto - nunca é demasiado relembrar -, isto é tanto mais impossível quanto se pensa numa obra que se desenvolve essencial e radicalmente a partir de forças e de relações de forças que não cessam de se incluir, de se excluir, de se repetir, de se superar e, por conseguinte, de se afirmar na diferença e no querer-mais. Se, portanto, dificilmente se encontraria - no texto nietzschiano - uma pretensa racionalidade na natureza guiando teleologicamente o curso das coisas, esta dificuldade só tenderia a aumentar se se tentasse nele descobrir uma suposta correspondência entre lei natural e lei escrita. Este binômio está totalmente ausente da dinâmica fundamental de seu pensamento, na medida em que a escrita ou o texto se apresenta, na sua concepção de base, como a impossibilidade mesma de se lançar um último significante sobre aquele pequeno resto que permanece em suspensão no movimento centrífugo do dizer, ou do significar. Em outros termos, entre o pensar e o dizer, ou o escrever, se desenrola a tensão infinita do desejo. Certo, isto vale não somente para a escrita de Nietzsche, mas também para toda escrita, ou para todo texto. Sem embargo, foi particularmente na filosofia contemporânea - e, sobretudo, na obra paradoxal de Nietzsche - que se evidenciou e se aprofundou a hiância que separa o sujeito e o pedido do sujeito, que lhe é sempre heterogêneo.

Essa hiância e essa tensão que caracterizam essencialmente o desejo se tornarão ainda mais acirradas se considerarmos o parágrafo 22 
de Para além de bem e mal, publicado em 1886, em que Nietzsche investe contra os paladinos das "leis da natureza" que, segundo o filósofo, se arrimam em interpretações que nada têm a ver com o texto. Certo, prossegue o filósofo, essas interpretações reivindicam uma "igualdade universal perante a lei", mas, na verdade, o que elas exprimem (e camuflam ao mesmo tempo) é o instinto democrático da alma moderna e uma aversão plebeia contra tudo aquilo que é aristocrático, potente e superior (NIETZSCHE, 1988, v. 5, p. 37). "Viva a lei natural!", exclamam esses físicos. Todavia, revida Nietzsche, trata-se aí de uma interpretação, e não de um texto. Com efeito, observa o autor, poderia muito bem sobrevir outro intérprete que, apoiando-se numa intenção e numa visão diametralmente opostas àquelas, detectasse na mesma natureza e nos mesmos fenômenos, não uma providência, não uma ordem ou uma finalidade emanando de um logos legislador, mas antes o triunfo tirânico e implacável das exigências e imposições da potência. No entanto, insiste o filósofo, o mesmo intérprete poderia afirmar deste mundo aquilo mesmo que afirmam os defensores da lei natural, a saber, que o seu curso é "necessário" e "previsível", e isto não em virtude de estar ele submetido a leis, mas justamente "porque lhe faltam absolutamente leis e porque toda potência, a cada momento, vai até as suas últimas consequências" (NIETZSCHE, 1988, v. 5, p. 37). Mas, pondera Nietzsche: "Admitindo-se que isto também não passe de uma interpretação? [...] Ora, tanto melhor" (NIETZSCHE, 1988, v. 5, p. 37).

Efetivamente - repita-se - o que está em jogo na escrita e no pensamento nietzschiano é a impossibilidade mesma de se dizer a última palavra, a última valoração, a última interpretação. Pois, dado que o texto, todo texto, aponta incessantemente para um construir e um destruir, um plasmar e um remodelar - cujo sentido só se dá, paradoxalmente, no movimento ex-cêntrico e heterogêneo de sua própria elisão, ou suspensão - segue-se que jamais se chegará a uma interpretação definitiva e verdadeira.

Certo, todo pensamento e toda escrita são indissociáveis um do outro. Mas em vão se procuraria uma correspondência unívoca e necessária entre o pensamento - ou um suposto logos inscrito na natureza - e o modo de dizê-lo, expressá-lo, escrevê-lo. É que, para falar 
lacanianamente: entre o significante e o significado se inter-cala, se inter-põe e se impõe o desejo na sua iterativa e sempre renovada satisfação-insatisfação. Mas é isso mesmo que faz pensar, é isso mesmo que faz criar ou, mais exatamente, recriar. Assim, se se objetasse que a lei natural e a lei escrita não são, afinal de contas, senão duas ficções a mais, poder-se-ia igualmente redarguir: "Ora, tanto melhor!".

\section{Referências}

AGOSTINHO, S. La Trinità. Roma: Città Nuova, 1998.

AGOSTINHO, S. Tutti i dialoghi. Milano: Bompiani, 2006.

ALMEIDA, R. M. de. Nietzsche e o paradoxo. São Paulo: Loyola, 2005.

AQUINO, T. de. Summa contra Gentiles. Notre Dame: University of Notre Dame Press, 1975. v. 3, II.

ARISTÓTELES. The Basic Works of Aristotle. New York: Random House, 1941.

ARNOULD, J. Les raisons séminales chez Saint Augustin. Augustinianum, Roma, v. 38, n. 2, p. 439-453, 1998.

GUTHRIE, W. K. C. The Greek Philosophers: from thales to Aristotle. New York: Harper, 1975.

JAEGER, W. Paideia: die Formung des griechischen Mensch. Berlin/New York: Walter de Gruyter, 1973.

NIETZSCHE, F. Kritische Studienausgabe. Berlin/New York: De Gruyter, 1988. v. 15.

PLATÃO. Gorgias. Plato in Twelve Volumes. Cambridge: Harvard University Press, 1975.

RADICE, R. (Ed.). Stoici Antichi: tutti i frammenti. Milano: Bompiani, 2006. 
312 ALMEIDA, R. M. de.

REALE, G. (Ed.). I Presocratici. Milano: Bompiani, 2006.

SÓFOCLES. Antigone. Milano: BUR, 2004.

Recebido: 12/10/2011

Received: 10/12/2011

Aprovado: 24/03/2012

Approved: 03/24/2012

Rev. Filos., Aurora, Curitiba, v. 24, n. 34, p. 289-312, jan./jun. 2012 